\title{
Why there is an Increased Risk of Cardiac Failure, Widening of Pulse Pressure and Hemorrhagic Stroke in Type 2 Diabetics Over Age 60: Roles of Unrecognized Hypomagnesemia and Epigenetics Coupled with Increased Levels of Ceramides, Cytokines, ROS, 4-HNE and Platelet-Activating Factor
}

\author{
Burton M Altura ${ }^{1-7 *}$, Anthony Carella ${ }^{1,6}$, Asefa Gebrewold ${ }^{1}$, Nilank C Shah ${ }^{1,5}$, Bella T Altura ${ }^{1,3-7}$, Lawrence M Resnick ${ }^{8}$, and Simon \\ Halevy ${ }^{9}$
}

${ }^{1}$ Department of Physiology and Pharmacology, SUNY Downstate Medical Center, New York, USA

${ }^{2}$ Department of Medicine, SUNY Downstate Medical Center, New York, USA

${ }^{3}$ The Center for Cardiovascular and Muscle Research, SUNY Downstate Medical Center, New York, USA

${ }^{4}$ The School of Graduate Studies in Molecular and Cellular Science, SUNY Downstate Medical Center, New York, USA

${ }^{5}$ Bio-defense Systems, Inc, Rockville Centre, New York, USA

${ }^{6}$ Orient Biomedica, Inc, Estero, Florida, USA

${ }^{7}$ Magnesium for Health Foundation, Patterson, CA, USA

${ }^{8}$ Department of Medicine, Cornell University College of Medicine, New York, USA

${ }^{9}$ Department of Anesthesiology, SUNY Stonybrook School of Medicine, Stonybrook, New York, USA

*Corresponding author: Burton M Altura, Professor, Department of Physiology and Pharmacology, SUNY Downstate Medical Center, Brooklyn, New York, USA, Tel: 718-270-2194; E-mail: burton.altura@downstate.edu

Received: 14 Mar, 2020 | Accepted: 18 Apr, 2020 | Published: 23 Apr, 2020

Citation: Altura BM, Carella A, Gebrewold A, Shah NC, Altura BT, et al. (2020) Why there is an Increased Risk of Cardiac Failure, Widening of Pulse Pressure and Hemorrhagic Stroke in Type 2 Diabetics over Age 60: Roles of Unrecognized Hypomagnesemia and Epigenetics Coupled with Increased Levels of Ceramides, Cytokines, ROS, 4-HNE and Platelet-Activating Factor. J Clin Case Stu 5(2): dx.doi.org/10.16966/2471-4925.198

Copyright: (C) 2020 Altura BM, et al. This is an open-access article distributed under the terms of the Creative Commons Attribution License, which permits unrestricted use, distribution, and reproduction in any medium, provided the original author and source are credited.

\begin{abstract}
Despite more than 80 years of intensive and outstanding research, it remains to be determined how Type 2 (non-insulin dependent) Diabetes (T2D) results in extensive angiopathy and elevated Pulse Pressure (PP) in patients over 60 years of age, with large risks for heart attack or stroke. We present below a summary of recent findings from our laboratories which may give us clues to a better understanding of these very dangerous pathologies. Our studies present cogent reasons for why T2D is a multivariate syndrome with numerous pitfalls. T2D appears to be due, in origin, to numerous pathological pathways working in concert which lead to elevated PP (in the elderly), heart failure and/or stroke. Our observations on isolated animal tissues and cells as well as T2D subjects support a major role for $\mathrm{Mg}$ deficiency as a prime trigger leading to the production and release of ceramides (and possibly other sphingolipids), certain phospholipids (i.e., PKC isozymes), membrane peroxidation, activation of NADPH oxidase, Platelet-Activating Factor (PAF), reactive oxygen and nitrogen species, and release/generation of cytokines and adhesion molecules, all of which can be ameliorated by increased dietary intake and supplemental Mg. Based on extensive biochemical and biophysical-molecular assays, performed in our labs (reviewed herein), we are convinced that long-term $\mathrm{Mg}$ deficiency produces genotoxic effects which cause epigenetic alterations (e.g., angiogenetic/atherogenic) in cell phenotypes resulting in micro- and microvascular changes in T2D patients.
\end{abstract}

Keywords: Pulse pressure; Diabetes; Heart failure; Mg deficiency; Ceramides; Platelet-activating factor

\section{Introduction}

Ever since diabetic angiopathy, characterized by abnormal angiogenesis, was identified as a clinical entity, approximately 80 years ago, a growing awareness seems to indicate that this major complication of both type 1 (T1D) and type 2 (T2D) diabetes must be caused by either morphologic changes in the microvasculature, or by a primary functional metabolic disturbance(s) which is followed by structural vascular lesions. In addition, as T2D patients age (i.e., >60), their Pulse Pressure (PP) widens significantly (e.g., see Table 1) [1,2].
However, despite more than 80 years of intensive research, it remains to be determined how this angiopathy and widened PP develop. The lack of highly sophisticated in-vivo, non-invasive biophysical and biochemical techniques which are needed to diagnose, early, the microvascular structural and hemorheological alterations in the heart and brain, unfortunately, has often missed the potential underlying changes which can lead to cardiac failure and/or stroke in people over 60 years of age. About seven in 10 people over 65 with diabetes will die of heart disease and one in six from a stroke. 
Table 1: Progressive widening of pulse pressure and reduction in RBC $\mathrm{Mg}^{2+}$ with age in T2D subjects.

\begin{tabular}{|c|c|c|c|}
\hline Age (years) & Systolic BP & Diastolic BP & $\mathbf{R B C}_{\mathbf{~ M g}}{ }^{\mathbf{}}$ \\
\hline $25-38$ & $118 \pm 14$ & $82 \pm 8$ & $252 \pm 18$ \\
\hline $51-65$ & $128 \pm 12$ & $76 \pm 8$ & $228 \pm 10$ \\
\hline $66-76$ & $134 \pm 10$ & $69 \pm 9$ & $206 \pm 12$ \\
\hline $77-86$ & $138 \pm 8$ & $65+/ 10$ & $198 \pm 8$ \\
\hline
\end{tabular}

All values are means \pm S.E.M. All values within a group are different from one another ( $\mathrm{P}<0.05, \mathrm{ANOVA})$. All subjects were white males. $\mathrm{RBC} \mathrm{Mg}^{2+}$ was measured using 31P-NMRS. N=18-52/group.

\section{Despite lifestyle modification, weight reduction and medication, T2D diabetes leads to high risk for cardiomyopathy and hemorrhagic stroke}

Although the clinician often diagnoses T2D on the basis of elevated serum glucose and HbAlc in the elderly, other factors must be excluded such as pancreatic disease, injury or rare syndromic or genetic forms of diabetes. To these factors, the clinician usually adds age, family history, ethnicity, mental health, medications, biochemical profile, lifestyle and body weight, often making a T2D diagnosis problematical. Early diagnosis of T2D will often prevent the sequelae of events leading to uncontrolled T2D. However, in people over 60 years of age this often becomes difficult and can result in early cardiac failure and/or hemorrhagic stroke; the greater the duration of T2D, the higher the risk for intracerebral hemorrhage [3]. Poor control of $\mathrm{HbAlc}$ appears to be a cardinal sign for T2D-induced intracerebral hemorrhage $[4,5]$. But, why are many of these patients obese and have underlying kidney diseases is not clear? What is the connection to $\mathrm{T} 2 \mathrm{D}$ ?

For the approximately 450 million people living with diabetes, about $90 \%$ suffer from T2D. These patients present with beta-cell failure and resistance to insulin. Although diet is believed to play an important (maybe critical) role in early development of T2D, it is not clear as to why [6].

\section{Diabetics exhibit low cellular levels of ionized Mg coupled to elevated levels of calcium}

Over the past several years, a number of epidemiological/metanalyses studies have appeared, in the literature, to indicate that dietary magnesium intake is inversely associated with the incidence of T2D around the globe [3,7-10].

Approximately 40 years ago, two of us suggested that alterations in the calcium and magnesium contents (and their membrane transport mechanisms) could be major factors in development of diabetic angiopathy which lead to cardiac failure [11-13]. More recently, our laboratories helped to develop new $\mathrm{Mg}^{2+}$ ion selective electrodes which can rapidly, and accurately, measure the biologically-active $\mathrm{Mg}^{2+}$ as well as $\mathrm{Ca}^{2+}$ in whole blood, serum, plasma and cerebral spinal fluid in less than two minutes [14-19]. Using this new tool coupled with 31P-Nuclear Magnetic Resonance Spectroscopy (31P-NMRS) we have been able to accurately measure free $\mathrm{Mg}^{2+}$ levels in whole blood, serum, plasma and CSF, as well as cellular levels of free $\mathrm{Mg}^{2+}$ and $\mathrm{Ca}^{2+}$ in both T1D and T2D patients as well as in women with gestational diabetes [19-34]. Our results clearly demonstrate that both T1D and T2D diabetic patients exhibit significant deficits in cellular, cardiac and brain
$\mathrm{Mg}^{2+}$; the longer the patient had either T1D or T2D diabetes, and the older the subject, the lower was the serum, cellular, cardiac, and brain $\mathrm{Mg}^{2+}$ ([19-34], unpublished findings). These alterations were inversely proportional to the elevation in free $\mathrm{Ca}^{2+}$ levels in the cells and tissues. Interestingly, we also noted that racial factors were observed; i.e., the deficits in $\mathrm{Mg}^{2+}$ and elevations in $\mathrm{Ca}^{2+}$ were significantly $(\mathrm{P}<0.01)$ greater in the black compared to white population matched for age and sex [31]. To us, this is not surprising, as the black population is known to have greater genetic risks for heart attacks, diabetic-induced nephropathy and strokes, particularly in the T2D diabetic population. But, why should low $\mathrm{Mg}^{2+}$ in both tissues and cells coupled to elevated levels of $\mathrm{Ca}^{2+}$ provoke microvascular angiopathy and high-risk for cardiac failure, renal failure and strokes in T2D diabetics?

Low cellular levels of $\mathrm{Mg}^{2+}$ coupled to elevated cellular levels of $\mathrm{Ca}^{2+}$ results in central and peripheral vasoconstriction and vasospasm of most all types of microvessels, arteries and veins leading to decreased microvascular blood flows, coronary arterial ischemia and hypertension

Approximately 50 years ago, two of us found that lowering the extracellular level of $\mathrm{Mg}^{2+}$ surrounding both large and small blood vessels from the periphery, kidneys, heart and brain (from a variety of mammals (including humans) resulted in intense vasospasm; the lower the external $\mathrm{Mg}^{2+}$ level, the greater the degree of vasospasm [21-23,35-57]. Careful measurement of the blood vessel $\mathrm{Ca}^{2+}$, as predicted by us, revealed increased cellular levels of $\mathrm{Ca}^{2+}[21,26,30,35-$ $37,41,42,44,45,48,50,52,55,56,58-61]$. Using intact rats and dogs, and studying the intact microcirculation with TV quantitative microscopy (at magnifications $>6,000 \mathrm{x}$ ), we found identical results to match the findings we obtained on the isolated blood vessels ([21,37,41,42,55-57], unpublished findings). Collectively, such results would explain how, over a period of years, as the microvascular vessels became exposed to low dietary intake of $\mathrm{Mg}$ and continual T2D-induced depletion of $\mathrm{Mg}$, along with elevated intracellular $\mathrm{Ca}^{2+}$, this would, most likely, result in stiffening of blood vessels, hypertension, and ischemia in coronary, renal blood vessels and cerebral blood vessels, as well as a widening of PP, thus resulting in Ischemic Heart Disease (IHD), cardiac failure, renal failure and/or stroke. Our laboratories were the first to report that dietary $\mathrm{Mg}$ deficiency in experimental animals, under carefully controlled conditions, would lead to elevations in both systolic and diastolic blood pressure $[21,22,47]$. Several years after our latter publication, others confirmed several of our findings [62,63]. There is now an overwhelming amount of clinical evidence to show that hypomagnesemia is, indeed, linked to heart disease, IHD, diabeticlinked heart disease (and stroke) and sudden-cardiac death in infants , children and young adults (see [1-3,7,12,13,15,27,28,30,40,54-57,6473], among many other studies).

Low extracellular levels of $\mathrm{Mg}^{2+}$ lead to synthesis and release of sphingolipids and phospholipids in vascular smooth muscle cells and cardiac myocytes

In the early 1990's, working with 31P-NMRS and Proton-NMRS (1H-NMRS), and isolated vascular smooth muscle cells, we noted that low $\left[\mathrm{Mg}^{2+}\right]_{0}$ induced formation of a variety of sphingolipids and phospholipids $[74,75]$. We found that several of the sphingolipids, particularly ceramides, exert potent contractile effects on arterial and arteriolar blood vessels, including those in the heart, brain and periphery [76-78]. In addition, in the rat brain, using direct in-vivo quantitative video microscopy (at magnifications $>6,000 \mathrm{x}$ ), we found that several of the ceramides induced potent venular vasoconstriction 
followed by adhesion (sticking) of leukocytes, macrophages and monocytes to the postcapillary venular walls leading to petechial hemorrhages and transudation of blood- formed elements into the brain perivascular tissues, similar to a hemorrhagic stroke $[76,78]$.

These observations became quite intriguing to us and we, therefore, pursued them and noted that low $\mathrm{Mg}^{2+}$ induced/stimulated a variety of cellular signaling pathways, including up-regulation of diverse PKC isozymes and other phospholipids (e.g., DAG) $[79,80]$ which we believe underlie many reasons for why and how T2D diabetes can result in high blood pressure, inflammations, ischemia, elevated $\mathrm{PP}$, cardiac failure, renal failure and/or stroke. Several years after our Mg-sphingolipid studies were published, other investigators reported indications that synthesis/releases of diverse sphingolipids may be instrumental in the origin of T2D [81-84].

Low $\mathrm{Mg}^{2+}$ induces formation and release of ceramides and Platelet-Activating Factor (PAF) in vascular muscle cells: Potential relationship to diabetic angiopathy, cardiac failure and strokes

$\mathrm{Mg}^{2+}$ is a co-factor for more than 500 enzymes in the body. All energy-generating pathways as well as most carbohydrate, lipid, nucleotide, and protein synthetic pathways require $\mathrm{Mg}^{2+}$ [85]. Membrane transport of cations require $\mathrm{Mg}^{2+}[20,48,85]$. Examination of vascular and cardiac muscle exposed to low $\mathrm{Mg}^{2+}$ revealed, to us, for the first time that all enzymes involved in the synthesis and release of ceramides, surprisingly, were up-regulated both in in-vitro and in-vivo [78,79,86-90]. These Mg-deficient environments also resulted in increased levels of sphingosine, sphingosine-1-phosphate, Diacylglycerol (DAG), and diverse PKC isozymes [54,55,57,78,79,91].

Our labs, using intact animals and isolated blood vessels reported that, depending upon vessel type, and vascular tone, the sphingolipids resulted in contraction (and reduced blood flows) or sometimes vasodilation [57,75-78,91-94]. Collectively, these studies showed that coronary, renal and cerebral blood vessels underwent contraction and reduced blood flows when stimulated with a variety of ceramides. In addition, we found that a number of the ceramides and other sphingolipids resulted in increased membrane transport of $\mathrm{Mg}^{2+}$, increased membrane permeability, and inflammatory responses in cerebral, intestinal and skeletal muscle microvascular beds ([78,95], unpublished findings). When all these physiological actions of the ceramides, sphingolipids and phospholipids are taken into consideration, one must conclude that low dietary Mg intake and/or errors in Mg metabolism could underlie the observed detrimental cardiac, renal and cerebral effects of T2D.

However, on closer examination of our early 31P-NMRS and proton-NMRS data, we noted a synthesis and release of PAF and PAFrelated lipids when vascular smooth muscle cells were exposed to low $\mathrm{Mg}^{2+}[71,74,75,78]$. Further examination of responses of intact and isolated blood vessels revealed that these PAF molecules produced different degrees of contraction and increased permeability in the intestinal, skeletal muscle, and cerebral microvasculatures ([71,78], unpublished findings).

In 1992, Nathan and colleagues reported that bloods of T1D patients exhibited elevated levels of PAF [95]. Subsequently, other workers have reported similar findings [96]. Examination of the sera of several of our elderly T2D patients also revealed increased levels of both ceramides and PAF; the greater the duration of the
T2D, the higher the measured serum levels of both ceramides and PAF $(\mathrm{P}<0.01)$ [97]. The higher the serum levels of ceramides and PAF, the lower the serum levels of ionized Mg in our T2D patients $(\mathrm{P}<0.01)$ [97]. Given our findings, we must conclude that low $\mathrm{Mg}^{2+}$ levels in the T2D patients must perforce lead to synthesis and release of ceramides, DAG and PAF molecules.

Experiments done in our labs have confirmed that rat vascular smooth muscle and cardiac muscle exposed to low $\mathrm{Mg}$ lead to synthesis and release of ceramides, DAG, diverse PKC isozymes, and PAF [54,55,57,71-76,78,79]. Whether human-type 2 diabetic vascular smooth muscle and cardiac myocytes produce ceramides, DAG, PKC isozymes and PAF when exposed to low $\mathrm{Mg}$ in culture remains to be tested.

But are the synthesis and release of ceramides, the other phospholipids and PAF-related molecules totally responsible for the fibroses and angiogenic alterations observed in T2D patients or are they working in concert with cytokines like transforming growth factor-beta (TGF-beta)? It has been suggested that TGF-beta and adhesion molecules play important roles in T2D-induced nephropathy via inflammatory and fibrotic responses [98-101].

Low $\mathrm{Mg}^{2+}$ levels are associated with elevated levels of TGFbeta and other cytokines in vascular and cardiac muscle and sera of T2D subjects

Over the past several years, working with intact animals exposed to dietary deficiency of $\mathrm{Mg}$ (21 days) and isolated vascular smooth muscle cell, in primary cell cultures, exposed to low levels of $\mathrm{Mg}^{2+}$, we found, as predicted, that low levels of $\mathrm{Mg}^{2+}$ resulted in a synthesis and release of TGF-beta, IL-2, IL-6, TNF-alpha and the adhesion molecule VCAM-1 ([21,55,57,78,79,88], unpublished findings). Examination of the sera of several T2D patients, over 60 years of age, indicated that all these patients exhibited elevated levels of these cytokines and VCAM-1 [102]. Having this data, in view of the above sphingolipid and PAF findings, we are tempted to believe this presents a strong basis for how and why T2D patients over 60 years of age exhibit considerable inflammatory responses, elevated PP, hypertension, cardiomyopathy, renal diseases and a risk for intracerebral hemorrhagic stroke. However, how does one account for T2D patients over 60 years old presenting with accelerated atherogenesis?

Low serum $\mathrm{Mg}^{2+}$ levels in T2D subjects are associated with elevated levels of cholesterol, triglycerides and LDL in both animal and clinical studies: Relationship to atherogenesis and platelet aggregation

Approximately 30 years ago, two of us reported that dietary deficiency of $\mathrm{Mg}$ in rabbits coupled with elevated dietary levels of cholesterol induced very pronounced arterial plaques invested with elevated levels of cytokines, macrophagesand monocytes ([103], unpublished findings). Sera from these atherosclerotic animals demonstrated low levels of ionized $\mathrm{Mg}$ coupled to elevated levels of cholesterol, triglycerides and LDL, very similar to what has been found in many elderly T2D patients [104] as well as in our hospitals (e.g., see Table 2). More than 30 years ago, several workers reported increased platelet aggregation in the sera of T2D subjects [105,106]. We have found that the higher the degree of platelet aggregation, the higher the serum levels of both PAF and ceramides and the lower the serum level of ionized Mg in elderly TD2 patients [102]. All of these physiological alterations would produce atherogenesis. 
Table 2: Comparison of serum cholesterol, triglyceride, LDL and ionized $\mathrm{Mg}$ levels in young normal vs. elderly male T2D subjects.

\begin{tabular}{|c|c|c|c|c|}
\hline Age (years) & $\begin{array}{c}\text { Chol } \\
\text { (mmol/L) }\end{array}$ & $\begin{array}{c}\text { Trigly } \\
(\mathbf{m m o l} / \mathbf{L})\end{array}$ & $\begin{array}{c}\text { LDL } \\
\text { (mmol/L) }\end{array}$ & $\mathbf{M g}^{2+}$ (mmol/L) \\
\hline $25-38$ & $3.8 \pm 0.8$ & $1.6 \pm 0.4$ & $2.5 \pm 0.6$ & $0.68 \pm 0.08$ \\
\hline $77-86$ & $5.5 \pm 1.0$ & $2.6 \pm 0.6$ & $3.8 \pm 0.8$ & $0.58 \pm 0.06$ \\
\hline
\end{tabular}

All values are \pm S.E. M. All values within a group are different from one another $(\mathrm{P}<0.05, \mathrm{ANOVA})$. All subjects are same as table 1 .

\section{Roles of $\mathrm{Mg}$ in membrane peroxidation and generation of reactive oxygen and nitrogen species in T2D: Relation to angiogenesis and cell death}

In the late 1980 's, our laboratories noted that dietary deficiency of $\mathrm{Mg}^{2+}$, both in-situ and on isolated cardiovascular tissues and cells, as well as sera, resulted in membrane peroxidation of diverse cardiac and vascular muscle tissues, and generation of a number of ROS and Reactive Nitrogen Species (RNS) [54,55,57,71,74,107-110]. Very recently, we found that dietary deficiency of $\mathrm{Mg}$ (21 days) in rats resulted in an up-regulation of NADPH oxidase in all cardiovascular tissues and cells examined (i.e., 4-7-fold) ([78], unpublished findings). Activation of NADPH oxidase is known to produce superoxide radicals which lead to hydrogen peroxide $\left(\mathrm{H}_{2} \mathrm{O}_{2}\right)$, hydroxyl radicals $(\cdot \mathrm{OH})$ and peroxynitrite radicals $\left(\mathrm{ONOO}^{-}\right)$(for review, see [111]).

It has been reported that oxidative stress in $\mathrm{T} 2 \mathrm{D}$ patients is also associated with elevated serum and leukocyte levels of myeloperoxidase (MPO) [111-114]. Using some of our elderly T2D subjects, we have found a strong inverse relationship between $\mathrm{RBC}$ $\mathrm{Mg}^{2+}$ and MPO content $(\mathrm{P}<0.01)$ (unpublished findings). MPO is one of the most aggressive oxidants of ROS which usually results in elevated serum levels of hypochlorite $\left(\mathrm{OCl}^{-}\right)$which are found in T2D patients [112-118]. We have reported that $\mathrm{OCl}^{-}$, just like the other ROS, can promote constriction of blood vessels [119-124]. Studying the intact microcirculation and isolated vascular smooth muscle cells, we noted that every single ROS found in T2D patients (i.e.; $\mathrm{OH}, \mathrm{H}_{2} \mathrm{O}_{2}$, $\mathrm{OCl}^{-}$) or RNS (ONOO-) investigated, would promote constriction/ contraction of cerebral and peripheral blood vessels and increased vascular reactivity [78,123-124]. Many other investigators have reported similar pharmacological actions [e.g., 125,126]. Such actions clearly must perforce result in tissue ischemia, leading to hypoxic areas of no or little capillary/nutritional blood flow, stiffening of blood vessel walls, elevated PP and diverse inflammatory lesions.

In addition, as others have reported [116-118], we found progressive peroxidation in the T2D subjects, as exemplified by elevated serum levels of Malondialdehyde (MDA) (e.g., Table 3). Interestingly, but not surprising, as the MDA levels rose with age, the levels of two major anti-oxidants, Superoxide Dismutase (SOD) and Glutathione (GSH), declined with age (Table 3). The concentrations of the latter two moieties clearly parallel the $\mathrm{RBC} \mathrm{Mg}^{2+}$, while the concentrations of MDA is inversely proportional to the $\mathrm{RBC} \mathrm{Mg}^{2+}$ of the aged T2D subjects (Compare Table 1 with Table 3 ).

Lipid peroxidation by-product 4-Hydroxy-2-Nonenal (4$\mathrm{HNE}$ ) found in sera of T2D patients and in vascular muscle cells exposed to low $\mathrm{Mg}$

Approximately five years ago, our laboratories reported that when aortic, cerebral and neonatal piglet coronary vascular smooth muscle cells were exposed to low concentrations of $\left[\mathrm{Mg}^{2+}\right]_{0}$, in primary
Table 3: Progressive serum elevation of MDA concomitant with reduction in SOD and GSH in T2D subjects on aging.

\begin{tabular}{|c|c|c|c|}
\hline Age (years) & MDA(U/g Hb) & SOD(U/g Hb) & GSH(U/g Hb) \\
\hline $23-38$ & $1.28 \pm 0.24$ & $5.96 \pm 1.04$ & $3.75 \pm 0.68$ \\
\hline $66-76$ & $3.76 \pm 0.42$ & $3.46 \pm 0.56$ & $2.22 \pm 0.14$ \\
\hline $77-86$ & $4.24 \pm 0.48$ & $2.98 \pm 0.38$ & $1.88 \pm 0.12$ \\
\hline
\end{tabular}

All values are means \pm S.E.M. All values within a group are different from one another $(P<0.05)$. All subjects within a group are the same as in table 1.

Table 4: Serum elevation of 4-HNE-His adducts in elderly vs. young T2D subjects.

\begin{tabular}{|c|c|}
\hline Age (years) & Serum 4-HNE-His $(\boldsymbol{\mu m o l})$ \\
\hline $23-38$ & $0.22 \pm 0.04$ \\
\hline $77-86$ & $0.73 \pm 0.06$ \\
\hline
\end{tabular}

All values are means \pm S.E.M. Mean values for ages 77-86 years are sig. diff. from $28-38 \mathrm{yr}$ olds $(\mathrm{P}<0.001, \mathrm{t}$-test). 4-HNE-His analytes were determined with ELISA assays.

cultures, the cells generated 4-HNE [71]. 4-HNE, a major aldehyde product of lipid peroxidation in membranes, is known to exert numerous cytotoxic, genotoxic, biological and signaling actions [71,127-132]. 4-HNE is a forerunner of hydrogen peroxide production [130-132]. As little as $1.0 \mathrm{uM}$ of 4-HNE can produce chromosomal abnormalities and result in DNA fragmentation. Thus, low dietary $\mathrm{Mg}$ intake, over a period of years, could be expected to produce increased cellular and blood levels of 4-HNE, in T2D subjects over 60 years of age, as our investigation has now found (e.g., see Table 4). These new findings could be very important to the evolvement of the progressive microvascular structural-wall alterations, reduced nutritive-capillary blood flow, atherogenic, and inflammatory conditions observed in T2D patients. At about the time, we initiated our studies on 4-HNE, others reported evidence for 4-HNE induction of insulin-resistance in T2D subjects [133] and elevated 4-HNE adducts in sera of T2D patients with chronic periodontitis [134].

Interestingly, it has been reported that DNA damage and the DNA-damage response has been identified in human atherosclerosis $[135,136]$. As we demonstrated approximately 30 years ago, in a rabbit model, suboptimal dietary intake of $\mathrm{Mg}$ (similar to that which 65-75\% of the North Americans ingest daily) results in rapid atherosclerosis with plaques over more than $60 \%$ of the aortic and coronary arterial surfaces [103]. Recent human studies, using serial angiography coupled with postmortem studies, suggest that many plaques appear to invade coronary arterial walls before myocardial infarctions and in the absence of blood clots $[136,137]$. As indicated above, our earlier previous studies indicated that low $\left[\mathrm{Mg}^{2+}\right]_{0}$ environments lead to coronary arterial vasospasm and ischemia prior to plaque formation $[13,23,30,54,55,57,71,78,138]$. Depending upon the diverse types of DNA-modifications, cells in T2D patients (i.e., vascular, cardiac and endothelial cells) would exact different repair processes in-situ in order to attempt to remove such damage. Thus, it would be important to keep in mind that both DNA damage and synthesis could be expected in diverse tissues, in vivo, depending upon time and circulating/ cellular levels of free ionized Mg. Using this hypothesis, we have recently posited how hypomagnesemia may underlie an "epigenetic" basis for disturbances leading to cardiovascular tissue and disease states $[78,91,138-141]$. 


\section{ROS, RNS and 4-HNE can lead to various forms of cell death}

All of the ROS, RNS and 4-HNE molecules, mentioned above, have been found to lead to angiogenesis/atherogenesis [78,116-118] and various forms of programmed cell death (i.e., apoptosis, necroptosis), which are hallmarks of atherogenesis. We have found, using scanning $\mathrm{EM}$, that low Mg diets or primary cultured VSMC exposed to low $\mathrm{Mg}^{2+}$ lead to several forms of programmed cell death (i.e., apoptosis, necroptosis, ferroptosis, and pyroptosis) [78,110,142-144].

We are convinced that these associations are more than coincidental. However, the hypotheses in this paper must remain hypothetical until more rigorous studies are completed.

But it is, indeed, of considerable interest, to note here, that treatment of T2D as well as T1D subjects with $\mathrm{Mg}$, by different groups [6,145-153], including ours [32-34], appears to stabilize these patients metabolically and provide a better life style than just diabetic drugs, alone, which often have very dangerous side effects.

\section{Daily intake of bioavailable $\mathrm{Mg}$ in drinking water should go a long-way to the amelioration/prevention of vascular and cardiac damage in $T 2 D$ patients}

We believe, at the very least, that the evidence presented here in, adds considerable support to the hypothesis suggested more than two decades ago $[154,155]$ that water intake (from tap waters, well waters, bottled waters, and beverages using tap/well/spring waters) in humans varying between one and two liters/day with $\mathrm{Mg}^{2+}$ intakes varying from 20 to $>100 \mathrm{mg} / \mathrm{l}$, may, as we have suggested recently $[54,79,86,87,90,138]$, represent an excellent way to overcome and control marginal intakes of $\mathrm{Mg}$ obtained with most Western diets (with shortfalls of between 250-350 mg Mg/day). Moreover, in view of our findings and those of others [6,146-153], it is probably propitious to suggest that all desalinated-purified recovered/recycled waters, harvested rain waters, well waters, and all bottled waters given to humans to drink should be supplemented with bioavailable $\mathrm{Mg}^{2+}$ to ameliorate the induction of cardiovascular risk factors, disease processes, and the progression of diabetic disease processes worldwide.

\section{Conclusions and Future Thoughts}

Herein, we present a summary of recent findings from our laboratories which reveal a new hypothesis for why people over the age of 60 often develop a T2D disease which has numerous microvascular and macrovascular manifestations that are difficult to diagnose and treat. Our studies also present cogent reasons for why T2D is a multivariate syndrome with numerous pitfalls. T2D appears to be due, in origin, to numerous pathophysiological pathways which lead to heart failure, elevated PP and strokes. We also present observations and investigations on isolated tissues and cells as well as T2D patients which we believe support major roles for $\mathrm{Mg}$ deficiency as a prime trigger leading to the production and release of ceramides (and possibly other sphingolipids), phospholipids, membrane peroxidation, 4-HNE adducts, PAF molecules, ROS, and RNS together with cytokines and adhesion molecules, all of which can be ameliorated with $\mathrm{Mg}$ supplementation. It is clear that our hypothesis can, and should, be tested, particularly as there are inhibitors available which can block the synthesis of both ceramides and PAF.

\section{Acknowledgements}

The authors acknowledge that many of our studies were supported in part by research grants from The National Heart, Lung and Blood
Institute to BMA and BTA and some unrestricted research grants from certain pharmaceutical companies (i.e., Sandoz Pharmaceuticals; The Bayer Co.; The Upjohn Co; CIBA-Geigy Corp.) as well as kind donors. While some of our animal and human studies were ongoing, Professor Lawrence M Resnick, Professor Simon Halevy, and forensic scientist Anthony Carella passed away. These eminent scientists will be sorely missed.

\section{References}

1. Cockcroft JR, Wilkinson IB, Evans M, McEwan P, Peters JR, et al. (2005) Pulse pressure predicts cardiovascular risk in patients with type 2 diabetes mellitus. Am J Hypertens 18: 1463-1467.

2. Alemi H, Khaloo P, Ali Mansoumia MA, Rabizadan S, Salehi SS, et al. (2018) Pulse pressure and diabetes treatments: Blood pressure and pulse pressure difference among glucose lowering modality groups in type 2 diabetes. Medicine (Baltimore) 97: e9791.

3. Fang X, Wang K, Han D, He X, Wei J, et al. (2016) Dietary magnesium intake and the risk of cardiovascular disease, type 2 diabetes, and all-cause mortality: a dose-response meta-analysis of prospective cohort studies. BMC Med 14: 210.

4. Zhang G, Wu F, Xu Y, Feng J, Cai Z, et al. (2015) Prestroke glycemic status is associated with the functional outcome in spontaneous intracerebral hemorrhage. Neurol Sci 36: 927-934.

5. Okada T, Nakao T, Matsumoto H, Shino T, Nagaoka Y, et al. (2007) Association between markers of glycemic control, cardiovascular complications and survival in type 2 diabetic patients with end-stage renal disease. Intern Med 46: 807-814.

6. Sami W, Ansari T, Butt NS, Ab Hamid MR (2017) Effect of diet on type 2 diabetes mellitus: A review. Int J Health Sci (Qassim) 11: 65-71.

7. Larsson SC, Wolk A (2007) Magnesium intake and risk of type 2 diabetes: a meta-analysis. J Int Med 262: 208-214.

8. Dong JY, Xun P, He K, Qin LQ (2011) Magnesium intake and risk of type 2 diabetes. Diabetes Care 34: 2116-2122.

9. Dasgupta A, Sarma D, Saikia UK (2012) Hypomagnesemia in type 2 diabetes mellitus. Indian J Endocrinol Metab 16: 1000-1003.

10. Kurstjens S, de Baiij JHF, Bours H, Bindels RJM, Tack CJ, et al. (2017) Determinants of hypomagnesemia in patients with type 2 diabetes mellitus. Eur J Endocrinol 176: 11-19.

11. Altura BM, Halevy S, Turlapaty PDMV (1979) Vascular smooth muscle in diabetes and its influence on the reactivity of blood vessels. In: Davis (eds) The Microcirculation in Diabetes Mellitus. Volume 8, Advance in Microcirculation, Karger, Basel 118-150.

12. Altura BM, Altura BT (1985) New perspectives on the role of magnesium in the pathophysiology of the cardiovascular system. I. Clinical aspects. Magnesium 4: 226-244.

13. Altura BM (1988) Ischemic heart disease and magnesium. Magnesium 7: 57-67.

14. Altura BT, Shirey TL, Young CC, Hiti J, Dell'Orfano K, et al. (1992) A new method for the rapid determination of ionized $\mathrm{Mg}^{2+}$ in whole blood, serum and plasma. Methods Find Exp Clin Pharmacol 14: 297-304.

15. Altura BT, Altura BM (1992) Measurement of ionized magnesium in whole blood, plasma and serum with a new ion-selective electrode in healthy and diseased human subjects. Magnes Trace Elem 10: 90-98. 
16. Altura BT, Shirey TL, Young CC, Dell'Orfano K, Altura BM (1992) Characterization and studies of a new ion selective electrode for free extracellular magnesium ions in wholeblood, plasma and serum. In: Electrolyte/Blood Gas Division AACC, D'Orazio P, Burritt MF, Sena SF (eds) Electrodes, blood gases and other critical analytes: The patient, the measurement, and the government. Volume 14, Omni Press WI 152-173.

17. Altura BT, Shirey TL, Young CC, Dell'Orfano K, Hiti J, et al. (1994) Characterization of a new ion-selective electrode for ionized magnesium in whole blood, plasma, serum and aqueous samples. Scand J Clin Lab Invest Suppl 224: 21-36.

18. Altura BM (1994) Introduction: Importance of Mg in physiology and medicine and the need for ion selective electrodes. Scand J Clin Lab Invest Suppl 217: 5-9.

19. Altura BM, Altura BT (1996) Role of magnesium in pathophysiological processes and the clinical utility of magnesium ion -selective electrodes. Scand J Clin Lab Invest Suppl 224: 211-234.

20. Altura BM, Altura BT (2016) Importance of ionized magnesium measurements in physiology and medicine and the need for ionselective electrodes. J Clin Case Studies 1: 1-4.

21. Altura BM (1982) Magnesium and regulation of contractility. In: Altura BM (eds) Ionic Regulation of the Microcirculation, Advances in microcirculation. Volume 11, Karger, Basel 77-113.

22. Altura BM, Altura BT (1983) Influence of magnesium on vascular smooth muscle and serum biochemical parameters from diabetic and hypertensive rats. Magnes Exp Clin Res 2: 253-266.

23. Altura BM, Altura BT (1990) Magnesium and the cardiovascular system: Experimental and clinical aspects updated. In: Sigel $\mathrm{H}$, Sigel A (eds) Metal ions in biological systems. Volume 26, Marcel Dekker Inc, New York 359-416.

24. Resnick LM, Gupta RK, Bhargava KK, Gruenspan H, Alderman MH, et al. (1991) Cellular ions in hypertension, diabetes, and obesity. A nuclear magnetic resonance spectroscopic study. Hypertension 17: 951-957.

25. Resnick LM (1992) Cellular ions in hypertension, insulin resistance, obesity, and diabetes. J Am Soc Nephrol 3: S78-S85.

26. Altura BM, Zhang A, Altura BT (1993) Magnesium, hypertensive vascular diseases, atherogenesis, subcellular compartmentation of $\mathrm{Ca}^{2+}$ and $\mathrm{Mg}^{2+}$ and vascular contractility. Mineral Electrolyte Metab 19: $323-336$

27. Resnick LM, Altura BT, Gupta RK, Laragh JH, Alderman $\mathrm{MH}$, et al. (1993) Intracellular and extracellular magnesium depletion in type 2 (non-insulin) dependent diabetes mellitus. Diabetologia 36: 767-770.

28. Altura BT, Burack JL, Cracco RQ, Galland L, Handwerker SM, et al (1994) Clinical studies with the NOVA ISE for IMg ${ }^{2+}$. Scand J Clin Lab Invest Suppl 217: 53-67.

29. Bardicef M, Bardicef O, Sorokin Y, Altura BM, Altura BT, et al (1995) Extracellular and intracellular magnesium depletion in pregnancy and gestational diabetes. Am J Obstet Gynecol 172: 1009-1013.

30. Altura BM, Altura BT (1995) Magnesium and cardiovascular diseases. In: Berthon $\mathrm{G}$ (eds) Handbook of metal-ligand interactions in biological fluids. Taylor \& Francis 822-842.

31. Resnick LM, Bardicef O, Altura BT, Alderman MH, Altura BM (1997) Serum ionized magnesium: relation to blood pressure and racial factors. Am J Hypertens 10: 1420-1424.
32. Djurhuus MS, Henriksen JE, Klitgaard NA, Bjaabjerg O, Thye-Ronn P, et al (1999) Effect of moderate improvement in metabolic control on magnesium and lipid concentrations in patients with type 1 diabetes. Diabetes Care 22: 546-554.

33. Djurhuus MS, Klitgaard NAH, Petersen KK, Blaabjerg O, Altura BM, et al (2001) Magnesium reduces insulin-stimulated glucose uptake and serum lipid concentrations in type 1 diabetes. Metabolism 50: 1409-1417.

34. Djurhuus MS, Vaag A, Altura BM, Altura BT, Klitgaard NA (2002) Skeletal muscle magnesium in identical twins, discordant for type 2 diabetes. Diabetes Metab 28: 201-207.

35. Altura BM, Altura BT (1971) Influence of magnesium on druginduced contractions and ion content in rabbit aorta. Am J Physio 220: 938-944.

36. Altura BM, Altura BT (1974) Magnesium and contraction of arterial smooth muscle. Microvasc Res 7: 145-155.

37. Altura BM, Altura BT (1978) Magnesium and vascular tone and reactivity. Blood Vessels 15: 5-16.

38. Altura BM (1979) Sudden-death ischemic heart disease and dietary magnesium intake: is the target site coronary vascular smooth muscle? Med Hypotheses 5: 843-848.

39. Altura BT, Altura BM (1980) Withdrawal of magnesium causes vasospasm while elevated magnesium produces relaxation of tone in cerebral arteries. Neurosci Lett 20: 323-327.

40. Turlapaty PD, Altura BM (1980) Magnesium deficiency produces spasms of coronary arteries: relationship to etiology of sudden death ischemic heart disease. Science 208: 198-200.

41. Altura BM, Altura BT, Carella A, Turlapaty PD (1981) Hypomagnesemia and vasoconstriction: Possible relationship to etiology of sudden death ischemic heart disease and hypertensive vascular diseases. Artery 9: 212-231.

42. Altura BM, Altura BT (1981) Role of magnesium ions in contractility of blood vessels and skeletal muscles. Magnesium Bull 3: 102-114.

43. Altura BT, Altura BM (1982) The role of magnesium in etiology of strokes and cerebrovasospasm. Magnesium 1: 277-291.

44. Altura BM, Altura BT, Carella A, Turlapaty PD (1982) $\mathrm{Ca}^{2+}$ coupling in vascular smooth muscle: $\mathrm{Mg}^{2+}$ and buffer effects on contractility and membrane $\mathrm{Ca}^{2+}$ movements. Canad J Physiol Pharmacol 60: 459-482.

45. Altura BM, Altura BT (1983) Magnesium-calcium interaction and contraction of arterial smooth muscles in ischemic heart diseases, hypertension and vasospastic disorders. In: Wester P (eds) Electrolytes and The Heart. Trans Medica, New York 41-56.

46. Altura BM, Altura BT, Carella A (1983) Magnesium-deficiencyinduced spasms of umbilical vessels: Relation to preeclampsia, hypertension, growth retardation. Science 221: 376-378.

47. Altura BM, Altura BT, Gebrewold A, Ising H, Gunther T (1984) Magnesium deficiency and hypertension: Correlation between magnesium -deficient diets and microcirculatory changes in situ. Science 223: 1315-1317.

48. Altura BM, Altura BT (1984) Magnesium, electrolyte transport and coronary vascular tone. Drugs 28: 120-142.

49. Altura BM, Altura BT (1986) Magnesium-calcium interrelationships in vascular smooth muscle. Magnesium Bull 8: 338-350. 
50. Altura BM, Altura BT, Carella A, Gebrewold A, Murakawa T, et al. (1987) $\mathrm{Mg}^{2+}-\mathrm{Ca}^{2+}$ interaction in contractility of vascular smooth muscle: $\mathrm{Mg}^{2+}$ versus organic calcium channel blockers on myogenic tone and agonist-induced responsiveness of blood vessels. Canad J Physiol Pharmacol 65: 729-745.

51. Murakawa T, Altura BT, Altura BM (1988) Importance of magnesium and potassium concentration on basal tone and 5-HT induced contraction in canine coronary artery. Br J Pharmacol 94: 325-334.

52. Zhang A, Cheng TP, Altura BM (1992) Magnesium regulates intracellular free ionized calcium concentration and cell geometry in vascular smooth muscle cells. Biochim Biophys Acta 1134: 25-29.

53. Altura BM, Barbour RL, Dowd TL, Wu F, Altura BT, et al. (1993) Low extracellular magnesium induces intracellular free $\mathrm{Mg}$ deficits, ischemia, depletion of high-energy phosphates and cardiac failure in intact working rat hearts: a 31P-NMR study. Biochim Biophys Acta 1182: 329-332.

54. Altura BM, Altura BT (1995) Magnesium in cardiovascular biology. Sci Med 2: 28-37.

55. Altura BM, Altura BT (1995) Magnesium and cardiovascular biology: An important link between cardiovascular risk factors and atherogenesis. Cell Mol Biol Res 41: 347-359.

56. Altura BT, Memon Zl, Zhang A, Cheng TP, Silverman R, et al. (1997) Low levels of serum ionized magnesium are found in stroke patients early after stroke which results in rapid elevation in cytosolic free calcium and spasm in cerebral vascular smooth muscle cells. Neurosci Lett 230: 37-40.

57. Altura BM, Altura BT (2007) Magnesium: forgotten mineral in cardiovascular biology and angiogenesis. In: Nishizawa N, Morii $\mathrm{H}$ Durlach J (eds) New Perspectives in Magnesium Research. Springer, London 239-260.

58. Altura BM, Altura BT (1977) Extracellular magnesium and contraction of vascular smooth muscle. In: Casteels R, Godfraind T, Ruegg JC (eds) Excitation-Contraction Coupling of Smooth Muscle. North-Holland Publ Co, Amsterdam 137-144.

59. Turlapaty PDMV, Altura BM (1978) Extracellular magnesium ions control calcium exchange and content of vascular smooth muscle. Eur J Pharmacol 52: 421-423.

60. Altura BM, Altura BT (1981) General anesthetics and magnesium ions as calcium antagonists. In: Weiss GB (eds) New Perspectives on Calcium Antagonists. American Physiological Society, Washington, DC 131-145.

61. Altura BM, Altura BT (1981) Magnesium modulates calcium entry and contractility in vascular smooth muscle. In: Ohinishi ST, Endo M (eds) The Mechanism of Gated Calcium Transport Across Biological Membranes. Academic Press, New York 137-145.

62. Laurant P, Hayoz D, Brunner HR, Berthelot A (1999) Effect of magnesium deficiency on blood pressure and mechanical properties of rat carotid artery. Hypertension 33: 1105-1110.

63. Laurant P, Touyz R Schriffrin EL (1997) Effect of magnesium on vascular tone and reactivity in pressurized mesenteric resistance arteries from spontaneously hypertensive rats. Canad J Physiol Pharmacol 75: 293-300.

64. Goto K1, Yasue H, Okumura K, Matsuyama K, Kugiyama K, et al (1990) Magnesium deficiency detected by intravenous loading test in variant angina pectoris. Am J Cardiol 65: 709-712.

65. Seelig MS (1980) Magnesium in the Pathogenesis of Disease: Early Roots of Cardiovascular, Skeletal, and Renal Abnormalities. Plenum Publishing Corporation, New York.
66. Simko $F$ (1994) Pathophysiological aspects of the protective effect of magnesium in myocardial infarction. Acta Med Hung 50: 55-64.

67. Sataka K, Lee JD, Shinizu H, Ueda T, Nakamura T (1996) Relation between severity of magnesium deficiency and frequency of anginal attacks in men with variant angina. Am J Coll Cardiol 28: 897-902.

68. Sueda S, Fukuda H, Watanabe K, Suzuki J, Saeki H, et al. (2001) Magnesium deficiency in patients with recent myocardial infarction and provoked coronary artery spasm. Jap Circ J 65: 643-648.

69. Touyz $R$ (2003) Role of magnesium in the pathogenesis of hypertension. Mol Aspects Med 24: 107-136.

70. Minato N, Katayama Y, Sakaguchi M, Itoh M (2006) Perioperative coronary artery spasm in off-pump coronary bypass grafting and its possible relation with perioperative hypomagnesemia. Ann Thorac Cardiovasc Surg 12: 32-36.

71. Altura BM, Li W, Zhang A, Zheng T, Shah NC, et al. (2016) The expression of platelet-activating factor is induced by low extracellular $\mathrm{Mg}$ in aortic, cerebral and neonatal coronary vascular smooth muscle; cross-talk with ceramide production, NF-KB and proto-oncogenes: Possible links to atherogenesis and sudden cardiac death in children and infants, and aging: Hypothesis, review and viewpoint. Int J Cardiol Res 3: 47-67.

72. Altura BM, Li W, Zhang A, Shah GJ, Shah NC, et al. (2016) Sudden cardiac death in infants, children and young adults: Possible roles of dietary magnesium intake and generation of platelet-activating factor in coronary arteries. J Heart Health 2: 1-5.

73. Altura BM, Gebrewold A, Carella A, Shah NC, Shah GJ, et al. (2020) Is the widening of pulse pressure and hypertension in the elderly due in large measure to an unrecognized hypomagnesemia, downregulation of telomerase and progressive release of ceramides and platelet-activating factor? Biomed J Sci \& Technol Res 24: 18216-18219.

74. Morrill GA, Gupta RK, Kostellow AB, Ma GY, Zhang A, et al. (1997) $\mathrm{Mg}^{2+}$ modulates membrane lipids in vascular smooth muscle: a link to atherogenesis. FEBS Lett 408: 191-194.

75. Morrill GA, Gupta RK, Kostellow AB, Ma GY, Zhang A, et al. (1998) $\mathrm{Mg}^{2+}$ modulates membrane sphingolipids and lipid second messengers in vascular smooth muscle cells. FEBS Lett 440: 167-171.

76. Altura BM, Gebrewold A, Zheng T, Altura BT (2002) Sphingomyelinase and ceramide analogs induce vasoconstriction and leukocyteendothelial interactions in cerebral venules in the intact rat brain: Insight into mechanisms possible relation to brain injury and stroke. Brain Res Bull 58: 271-278.

77. Zheng T, Li W, Wang J, Altura BT, Altura BM (2000) Sphingomyelinase and ceramide analogs induce contraction and rises in $[\mathrm{Ca}(2+)](i)$ in canine cerebral vascular muscle. Am J Physiol Heart Circ Physiol 278: H1421-H1428.

78. Altura BM, Shah NC, Shah GJ, Altura BT (2018) Magnesium deficiency, sphingolipids and telomerase: Relevance to atherogenesis, cardiovascular diseases and aging. In: Preedy V, Vinood PB (eds) Handbook of Famine, Starvation and Nutrient Deprivation. Springer.

79. Altura BM, Shah NC, Shah GJ, Zhang A, Li W, et al. (2014) Shortterm $\mathrm{Mg}$ deficiency upregulates protein kinase $\mathrm{C}$ isoforms in cardiovascular tissues and cells: relation to NF-KB, cytokines, ceramide salvage sphingolipid pathway and PKC-zeta; hypothesis and review. Int J Clin Exp Med 7: 1-21. 
80. Yang ZW, Wang J, Zheng T, Altura BT, Altura BM (2000) Low [Mg(2+)] (o) induces contraction and $[\mathrm{Ca}(2+)](\mathrm{i})$ rises in cerebral arteries: roles of $\mathrm{ca}(2+)$, PKC, and PI3. Am J Physiol Heart Circ Physiol 279: H2898-H2907.

81. Summers SA, Nelson DH (2005) A role for sphingolipids in producing the common features of type 2 diabetes, metabolic syndrome $X$, and Cushing's syndrome. Diabetes 54: 591-602.

82. Russo SB, Ross Js, Cowart LA (2013) Sphingolipids in obesity, type 2 diabetes, and metabolic disease. Handb Exp Pharmacol 216: 373401.

83. Ross JS, Russo SB, Chavis GC, Cowart LA (2014) Sphingolipid regulators of cellular dysfunction in type 2 diabetes mellitus: a systems review. Clin Lipidol 9: 553-569.

84. Sui J, He M, Wang Y, Zhao X, He Y, et al. (2019) Sphingolipid metabolism in type 2 diabetes and associated cardiovascular complications. Exp Ther Med 18: 3603-3614.

85. de Baaij HF, Hoenderop JG, Bindels RJ (2015) Magnesium in man: Implications for health and disease. Physiol Rev 95: 1-46.

86. Altura BM, Shah NC, Li Z, Jiang XC, Zhang A, et al. (2010) Short-term magnesium deficiency upregulates sphingomyelinase synthase and p53 in cardiovascular tissues and cells: relevance to de novo synthesis of ceramide. Am J Physiol Heart Circ Physiol 299: H2046-H2055.

87. Altura BM, Shah NC, Li Z, Jiang XC, Perez-Albela JL, et al. (2010) Magnesium deficiency upregulates serine palmitoyltransferase (SPT1 and SPT2) in cardiovascular tissues and cells: relevance to serum ionized $\mathrm{Mg}$ and cytochrome C. Am J Physiol Heart Circ Physiol 299: H932-H938.

88. Altura BM, Shah NC, Shah GJ, Zheng T, Li W, et al. (2012) Shortterm magnesium deficiency upregulates ceramide synthase in cardiovascular tissues and cells: cross-talk among cytokines, $\mathrm{Mg}^{2+}$, NF- KB and de novo ceramide. Am J Physiol Heart Circ Physiol 302: $\mathrm{H} 319-\mathrm{H} 332$

89. Altura BM, Shah NC, Shah GJ, Li W, Zhang A, et al. (2013) Magnesium deficiency upregulates sphingomyelinases in cardiovascular tissues and cells: cross-talk among proto-oncogenes, $\mathrm{Mg}^{2+}, \mathrm{NF}-\mathrm{KB}$ and ceramide and their potential relationship to resistant hypertension, atherogenesis and cardiac failure. Int J Clin Exp Med 6: 861-869.

90. Shah NC, Shah GJ, Li Z, Jiang XC, Altura BT, et al. (2014) Short-term magnesium deficiency down regulates telomerase, upregulates sphingomyelinase and induces DNA damage in cardiovascular tissues: relevance to atherogenesis, cardiovascular diseases and aging. Int J Clin Exp Med 7: 497-514.

91. Zheng T, Li W, Altura BT, Altura BM (1998) $\mathrm{C}_{2}$-ceramide attenuates prostaglandin $\mathrm{F}_{2 \alpha}$-induced vasoconstriction and elevation of $\left[\mathrm{Ca}^{2+}\right]_{i}$ in canine cerebral vascular smooth muscle. Neurosci Lett 256: 113116.

92. Zheng T, Li W, Altura BT, Altura BM (1999) $\mathrm{C}_{2}$-ceramide attenuates phenylephrine-induced vasoconstriction and elevation in $\left[\mathrm{Ca}^{2+}\right]_{\text {in }}$ in rat aortic smooth muscle. Lipids 34: 689-695.

93. Zheng T, Li W, Wang J, Altura BT, Altura BM (2000) Effects of a neutral sphingomyelinase on phenylephrine-induced vasoconstriction and $\mathrm{Ca}^{2+}$ mobilization in rat aortic smooth muscle cells. Eur J Pharmacol 391: 127-135.

94. Zheng T, Li W, Altura BT, Shah NC, Altura BM (2011) Sphingolipids regulate $\left[\mathrm{Mg}^{2+}\right]_{0}$ uptake and $\left[\mathrm{Mg}^{2+}\right]_{i}$ content in vascular smooth muscle cells: potential mechanisms and importance to membrane transport of $\mathrm{Mg}^{2+}$. Am J Physiol Heart Circ Physiol 300: H486-H492.
95. Nathan N, Denizot Y, Hue Mc, Claverie C, Laubie B, et al. (1992) Elevated levels of paf-acether in blood of patients with type 1 diabetes mellitus. Diabetes Metab 18: 59-62.

96. Cavallo-Perini P, Lupia E, Gruden G, Olivetti C, De Martino A, et al. (2000) Increased blood levels of platelet-activating factor in insulindependent diabetic patients with microalbuminuria. Nephrol Dial Transplant 15: 994-999.

97. Altura BM, Carella A, Resnick LM, Halevy S, Altura BT (2020) Elderly type 2 diabetic patients exhibit low $\mathrm{RBC}\left[\mathrm{Mg}^{2+}\right]$, together with elevated serum levels of ceramides and platelet-activating factor.

98. Gomes KB, Rodrigues KF, Fernandez AP (2014) The role of transforming growth factor-beta in diabetic nephropathy. Int J Med Genetics 2014: 180270.

99. Zhu Y, Usui HK, Sharma K (2007) Regulation of transforming growth factor beta in diabetic nephropathy: implications for treatment. Semin Nephrol 27: 153-160.

100. Avci E, Uzeli S (2016) The role of adhesion molecules and cytokines in patients with diabetic nephropathy. Biomed Res 2016: S343-S348.

101. Navarro-Gonzalez JF, Mora-Fernandez C (2008) The role of inflammatory cytokines in diabetic nephropathy. J Am Soc Nephrol 19: 433-442.

102. Altura BM, Gebrewold A, Carella A, Resnick LM, Altura BT (2020) Low serum $\mathrm{Mg}$ levels found co-jointly with elevated platelet aggregation and serum levels of cytokines, chemokines and VCAM-1 in diabetic type 2 patients over 60 years of age.

103. Altura BT, Brust M, Bloom S, Barbour RL, Stempak J, et al. (1990) Magnesium dietary intake modulates blood lipid levels and atherogenesis. Proc Natl Acad Sci USA 87: 1840-1844.

104. van Hateren KJJ, Landman GWD, Kleefstra N, Logtenberg SJJ, Groenier $\mathrm{KH}$, et al. (2009) The lipid profile and mortality risk in elderly type 2 diabetes patients: A ten-year follow-up study (ZODIAC-13). PLoS ONE 4: e8464.

105. Ferroni P, Basili S, Falco A, Davi G (2004) Platelet activation in type 2 diabetes mellitus. J Thromb Haemost 2: 1282-1291.

106. Gresele P, Marzotti S, Guglielmini G, Momi S, Giannini S, et al. (2010) Hyperglycemia-induced platelet activation in type 2 diabetes is resistant to aspirin but not to a nitric oxide-donating-agent. Diabetes Care 33: 1262-1268.

107. Wu F, Altura BT, Gao J, Barbour RL, Altura BM (1994) Ferrylmyoglobin formation induced by low magnesium deficiency in perfused rat heart causes cardiac failure. Biochim Biophys Acta 1225: 158-164.

108. Altura BM, Gebrewold A, Zhang A, Altura BT (2003) Low extracellular magnesium induces lipid peroxidation and activation of nuclear factor-KB in canine cerebral vascular smooth muscle: possible relation to traumatic brain injury and strokes. Neurosci Lett 341: 189-192.

109. Altura BM, Kostellow AB, Zhang A, Li W, Morrill GA, et al. (2003) Expression of nuclear factor- $\mathrm{KB}$ and proto-oncogenes c-fos and c-jun are induced by low extracellular $\mathrm{Mg}^{2+}$ in aortic and cerebral vascular smooth muscle cells: possible links to hypertension, atherogenesis, and stroke. Am J Hypertens 16: 701-707.

110. Altura BM, Shah NC, Cheng XC, Li Z, Perez-Albela JL, et al. (2009) Short-term magnesium deficiency results in decreased levels of serum sphingomyelin, lipid peroxidation and apoptosis in cardiovascular tissues. Am J Physiol Heart Circ Physiol 297: H86-H92. 
111. Ozcan A, Ogun M (2015) Biochemistry of reactive oxygen and nitrogen species. In: Sivakumar Joghi Thatha Gowder (eds) Basic Principles and Clinical Significance of Oxidative Stress. BoD, IntechOpen, UK 37-58.

112. Wiersma JJ, Meuwese MC, van Miert JN, Kastelein A, Tijssen JG, et al. (2008) Diabetes mellitus type 2 is associated with higher levels of myeloperoxidase. Ned Sci Monit 14: CR406-CR410.

113. Kusuma KS, Vasudha RC, Vanitha GMN (2009) A comparative study of serum myeloperoxidase activity in type 2 diabetes and diabetic nephropathy. Biomed Res 20: 198-204.

114. Song $P$, Xu J, Song $Y$, Jiang $S$, Yuan $H$, et al. (2015) Association of plasma myeloperoxidase level with risk of coronary artery disease in patients with type 2 diabetes. Dis Markers 2015: 761939.

115. Singh PP, Mahadi F, Roy A, Sharma P (2009) Reactive oxygen species, reactive nitrogen species and antioxidants in etiopathogenesis of diabetes mellitus type 2. Indian J Clin Biochem 24: 324-342.

116. Kaneto H, Katakami H, Katakami N, Matsuhisa M, Matsoka TA (2010) Role of reactive oxygen species in the progression of type 2 diabetes and atherosclerosis. Mediators Inflamm 2010: 453892.

117. Fakhruddin S, Alanazi W, Jackson KE (2017) Diabetes-induced reactive oxygen species: Mechanism of their generation and role in renal injury. J Diabetes Res 2017: 8379327.

118. Volpe CMO, Villar-Delfino PH, Dos Anjos PMF, Nogueira-Machado JA (2018) Cellular death, reactive oxygen species (ROS) and diabetic complications. Cell Death Dis 9:119.

119. Liu JP, Li W, Altura BT, Altura BM (2017) Mechanisms of sodium hypochlorite-induced contraction of rat aorta: Potential importance in atherogenesis and apoptotic phenomena in cardiovascular diseases. J Heart Cardiovasc Res 1: 1-7.

120. Liu JP, Liu W, Li W, Zheng T, Altura BT, et al. (2017) Hypochlorite raises intracellular free $\mathrm{Ca}^{2+}$ in primary cultured smooth muscle cells of rat aorta: Participation of cellular signaling pathways. J Heart Cardiovasc Res 1: 1-7.

121. Yang ZW, Zheng T, Zhang A, Altura BT, Altura BM (1998) Mechanisms of hydrogen peroxide-induced contraction of rat aorta. Eur J Pharmacol 344: 169-181.

122. Yang ZW, Zheng T, Wang J, Zhang A, Altura BT, et al. (1999) Hydrogen peroxide induces contraction and raises $\left[\mathrm{Ca}^{2+}\right]_{i}$ in canine cerebral arterial smooth muscle: Participation of cellular signaling pathways. Naunyn Schmiedebergs Arch Pharmacol 360: 646-653.

123. Li J, Li W, Altura BT, Altura BM (2004) Mechanisms of hydroxyl radical-induced contraction of rat aorta. Eur J Pharmacol 499: 171178.

124. Li J, Li W, Su J, Liu W, Altura BT, et al. (2003) Hydrogen peroxide indices apoptosis in cerebral vascular smooth muscle cells: Possible relation to neurodegenerative diseases and strokes. Brain Res Bull 62: 101-106

125. Rubanyi GM (1988) Vascular effects of oxygen-derived free radicals. Free Rad Biol Med 4: 107-120.

126. Fattman CL, Schaefer LM, Oury TD (2003) Extracellular superoxide dismutase in biology and medicine. Free Rad Biol Med 35: 236-256.

127. Ecki PM (2003) Genotoxicity of HNE. Mol Aspects Med 24: 161-165.

128. Forman HJ, Dickinson DA, lles KE (2003) HNE-signaling pathways leading to its elimination. Mol Aspects Med 24: 189-194.
129. Siems W, Grune $T$ (2003) Intracellular metabolism of 4-hydrxynonenal. Mol Aspects Med 24: 167-175.

130. Schaur RJ (2003) Basic aspects of the biochemical reactivity of 4-hydroxynonenal. Mol Aspects Med 24: 144-159.

131. Chapple SJ, Cheng X, Mann GE (2013) Effects of 4-hydroxynonenal on vascular endothelial and smooth muscle redox signaling and function in health and disease. Redox biol 1: 319-331.

132. Schaur RJ, Siems W, Bresgen N, Ecki PM (2015) 4-Hydroxy-nonenal-A bioactive lipid peroxidation product. Biomolecules 5: 2247-2337.

133. Pillon NJ, Croze ML, Vella RE, Souliere L, Lagarde M, et al. (2012) The lipid peroxidation by-product 4-hydroxy-2-nonenal (4-HNE) induces insulin resistance in skeletal muscle through both carbonyl and oxidative stress. Endocrinology 153: 2099-2111.

134. Pradeep AR, Agarawl E, Baiel P, Rao NS (2013) 4-Hydroxy-2-nonenal, an oxidative stress marker in crevicular fluid and serum in type 2 diabetes with chronic periodontitis. Contemp Clin Dent 4: 281-285.

135. Gray K, Kumar S, Figg N, Harrison J, Baker L, et al. (2015) Effects of DNA damage in smooth muscle cells in atherosclerosis. Circ Res 116 : 816-826.

136. Razani B, Raines EW (2015) Can the DNA damage response be harnessed to modulate atherosclerotic plaque phenotype? Circ Res 116: 770-773.

137. Ahmadi N, Leipsic J, Blankenstein R, Taylor C, Hecht H, et al. (2015) Do plaques rapidly progress prior to myocardial infarction? The interplay between plaque vulnerability and progression. Circ Res 117: 99-104.

138. Altura BM, Zhang A, Murakawa T, Zheng T, Li W, et al. (2019) Can hypomagnesemia put the squeeze on coronary arteries: An unappreciated factor in myocardial ischemia, heart attacks and sudden cardiac death. EC Orthoped 10: 572-581.

139. Altura BM, Shah NC, Shah GJ, Altura BT (2016) Genotoxic effects of magnesium deficiency in the cardiovascular system and their relationships to cardiovascular diseases and atherogenesis. J Cardiovasc Dis Diagn S1: 008.

140. Altura BM, Shah NC, Shah GJ, Altura BT (2016) Magnesium deficiency results in oxidation and fragmentation of DNA, downregulation of telomerase activity, and ceramide release in cardiovascular tissues and cells: Potential relationship to atherogenesis, cardiovascular diseases and aging. Int J Diabetol Vasc Dis Res 4: 1-5.

141. Altura BM, Shah NC, Shah GJ, Handwerker S, Altura BT (2020) Emerging role of epigenetics in cardiovascular diseases: Importance of ionized hypomagnesemia. Int J Mol Biol Open Access 4: 202-204.

142. Altura BM, Shah NC, Shah GJ, Altura BT (2017) Regulated RIPK3 necroptosis is produced in cardiovascular tissues and cells in dietary magnesium deficiency: Roles of cytokines and their potential importance in inflammation and atherogenesis. J Med Surg Pathol 2: e104.

143. Altura BM, Gebrewold A, Carella A, Zhang A, Shah NC, et al. (2018) Regulated ferroptosis cell death is produced in cardiovascular tissues and cells in dietary magnesium deficiency; initiation of roles of glutathione, mitochondrial alterations and lipid peroxidation in inflammation and atherogenesis. EC Pharmacol \& Toxicol 6: 535-541.

144. Altura BM, Gebrewold A, Carella A, Zhang A, Shah NC, et al. (2019) Regulated pyroptosis is produced in cardiovascular tissues and cells in dietary magnesium deficiency: Cross-talk with cytokines, PAF, telomerases and aging. EC Pharmacol \& Toxicol 7: 25-30. 
145. Sjogren A, Floren CH, Nilsson A (1988) Oral administration of magnesium hydroxide to subjects with insulin-dependent diabetes mellitus: effects on magnesium and potassium levels and on insulin requirements. Magnesium 7: 117-122.

146. de Lordes Lima M, Cruz T, Pousada JC, Rodrigues LE, Barbosa K, et al. (1998) The effect of magnesium supplementation in increasing doses on the control of type 2 diabetes. Diabetes Care 21: 682-686.

147. Rodriguez-Moran M, Guerrero-Romero F (2003) Oral magnesium supplementation improves insulin sensitivity and metabolic control in type 2 diabetic subjects. Diabetes Care 26: 1147-1152.

148. Lopez-Ridaura R, Willett WC, Rimm EB, Liu S, Stampfer MJ, et al. (2014) Magnesium intake and risk of type 2 diabetes in men and women. Diabetes Care 27: 134-140.

149. Song Y, He K, Levitan EB, Manson Je, Liu S (2006) Effects of oral magnesium supplementation on glycaemic control in type 2 diabetes: a meta-analysis of randomized double-blind controlled trials. Diabet Med 23: 1050-1056.
150. Ghose B, Ide S (2014) Hypomagnesemia and type 2 diabetes mellitus: A review of the literature. Austin J Nutr Food Sci 2: 1025.

151. Solati M, Ouspid E, Hosseini S, Soltani N, Keshavarz M, et al. (2014) Oral magnesium supplementation in type II diabetic patients. Med J Islam Repub Iran 28: 67.

152. Chua FB, Cinco JE, Paz-Pacheco E (2017) Efficacy of magnesium supplementation on glycemic control in type 2 diabetes patients: A meta-analysis. J ASEAN Fed Endocr Soc 32: 38.

153. ElDerawi WA, NaserIA, Taleb MH, Abutair AS (2018) The effects of oral magnesium supplementation on glycemic response among type 2 diabetes patients. Nutients 11: E44.

154. Marier JR, Neri LC (1985) Quantifying the role of magnesium in the interrelationship between mortality/morbidity and water hardness. Magnesium 4: 53-59.

155. Leary WP (1986) Content of magnesium in drinking water and deaths from ischemic heart disease in white South Africans. Magnesium 5: 150-153. 